\title{
Study on the Liquefaction Resistance of Sand With Plastic And Non Plastic Fines
}

\author{
S.Boobathiraja ${ }^{1}$, P.Balamurugan ${ }^{2}$, C. Siva prakash $^{3}$, S.Ashwin ${ }^{4}$ \\ ${ }^{1 \&} 2$ Assistant Professor, Department of Civil Engineering, Erode Sengunthar Engineering College \\ ${ }^{3 \& 4} U$ G Students, Department of Civil Engineering, Erode Sengunthar Engineering College
}

\begin{abstract}
Liquefaction is the term commonly used to describe the sudden dramatic strength loss which occurs in sand during seismic loading. The quick sand condition can be achieved by developing a suitable model with detailed analysis and design to develop a critical hydraulic gradient in which the effective stress becomes zero. The parameter used to compare the results is the head of water. The plastic fines are the clay particles and the non plastic fine is the silt obtained from quarry dust. The head required for the sand to liquefy with $1,2 \%$ of the clay and silt is obtained. The resistance of sand to liquefaction with sand and silt is compared.
\end{abstract}

Keywords: - Non plastic fines, Plastic fines, Quick sand.

\section{INTRODUCTION}

Soil liquefaction describes a phenomenon whereby a soil substantially loses strength and stiffness in response to an applied stress, usually earthquake shaking or other rapid loading (force) causing it to behave like a liquid[1]. The phenomenon is most commonly observed in loose sandy soils. This is because a loose sand has a tendency to compress when a load is applied, dense sand by contrast tend to expand in volume or dilate .If the loading is rapidly applied and repetitive, the water pressure builds up in the soil. The result is pore water pressure becomes greater than the stresses acting between the soil grains. This causes the soil to lose its strength and flow like a liquid [2].

Quick sand is a simple example of liquefaction. Quick sand is a bed of soft or loose sand saturated with water and having considerable depth, yielding under weight and therefore tending to suck down any object resting on its surface[3].Quick sand is entirely a mechanical phenomenon and has nothing to do with solubility of materials in water or layers of variable density. Quick sand is achieved when the effective stress becomes zero.

Traditional quicksand is created when water seeps up from an underground source and saturates an area of sand, silt or any other grainy soil.

A review of studies has presented that the presence of silt and clay in some manner will affect the resistance of sand to liquefaction [4]. The need to clarify the effects of plastic and non plastic fines on the liquefaction susceptibility of sandy soils forms the major point of investigation in this work [5].

The formation of quick sands in nature may be said to occur when very fine particles of sand [6], occurring as loose deposits are acted upon by an upward seepage force.

This seepage force may be due to underground springs formed below such deposits or sudden rise of the water table at the site or water rise from the nearby sea beds. This seepage force neutralizes the self weight of the sand mass [10].

Good places to find quicksand are on ocean coasts, near sandy creek beds and area of sand over an impervious clay substructure. Another good place to find quicksand is in hilly country with abundant caves and underground springs lurking beneath. The desert country of the southwest is such a place and, since there is often no apparent source of water nearby.

\section{METHODOLOGY}

In this study the liquefaction resistances of sand with silt and clay are compared.

1) Sand passing through 300micron is used as the parent material and its properties were studied in the laboratory.

2) Silt obtained from quarry dust is used as non plastic fines. Its properties were determined in the laboratory.

3) Clay is used as the plastic fine. Its properties were determined in the laboratory by conducting various tests.

4) Model tank is designed, with detailed analysis and design to develop a critical hydraulic gradient in which the effective stress becomes zero.

5) The parameter used to compare the compare the results is the head of water.

6) The model study is first carried out for the parent material.

7) The head of water required for the sand to liquefy is at first obtained. 
8) The resistance of sand to liquefaction with silt and sand is obtained by conducting the model study with varying percentages of silt and clay. The percentage variation of silt and sand is selected as $1 \%$ and $2 \%$

9) The head of water required to cause liquefaction of sand with silt and clay is observed.

10) The results are then compared and conclusions are drawn.

\section{TESTS ON SAND}

The sand used for the study is Cauvery sand. The sand was tested in the laboratory to determine its properties such as Percentage of Gravel, Percentage sand, Percentage of silt, Specific gravity, minimum dry density maximum dry density, angle of internal friction.

The following tests were conducted in the laboratory to determine the above properties.
a) Sieve analysis
b) Pycnometer test
c) Relative density test
d) Direct shear test

The properties of sand obtained are given in table I

Table I Properties of sand

\begin{tabular}{|l|l|}
\hline Property & Values obtained \\
\hline Percentage gravel & $2.8 \%$ \\
\hline Percentage sand & $97 \%$ \\
\hline Percentage silt and clay & $0.2 \%$ \\
\hline $\begin{array}{l}\text { Specific gravity } \\
\text { Maximum dry density }\end{array}$ & 2.646 \\
\hline $\begin{array}{l}\text { Minimum dry density } \\
\text { Ǎ }\end{array}$ & $1.57 \mathrm{~g} / \mathrm{cm}^{3}$ \\
\hline $\begin{array}{l}\text { Angle of internal friction } \\
\Phi\end{array}$ & 36 \\
\hline
\end{tabular}

IV. TESTS ON PARENT MATERIAL

Sand passing through 300 micron sieve was used as the parent material. This silty sand obtained was tested in the laboratory for determining its properties such as Percentage of Gravel, Percentage sand, Percentage of silt and clay, Specific gravity, minimum dry density maximum dry density, angle of internal friction.

The following tests were conducted in the laboratory to determine the above properties.
a) Sieve analysis
b) Pycnometer test
c) Relative density test
d) Direct shear test

\section{PROPERTIES OF PARENT MATERIAL}

The properties of parent material obtained are given in table II Table II Properties of parent material

\begin{tabular}{|l|l|}
\hline Property & Values obtained \\
\hline Minimum dry density & $1.42 \mathrm{~g} / \mathrm{cm}^{3}$ \\
\hline Maximum dry density & $1.67 \mathrm{~g} / \mathrm{cm}^{3}$ \\
\hline Specific gravity & 2.753 \\
\hline Angle of internal friction & $2^{\circ}$ \\
\hline Density adopted for test & $1.6 \mathrm{~g} / \mathrm{cm}^{3}$ \\
\hline Relative density & $60 \%$ \\
\hline
\end{tabular}




\section{TESTS ON NON PLASTIC FINES-SILT}

The quarry dust particles were used as the silt. Tests were conducted in the laboratory for determining its properties such as Specific gravity and relative density.

The various properties of silt determined are summarized in Table III

Table III Properties of silt

\begin{tabular}{|l|l|}
\hline Property & Values obtained \\
\hline $\begin{array}{l}\text { Specificgravity } \\
\text { G }\end{array}$ & $\mathbf{2 . 8}$ \\
\hline Relative density & $\mathbf{4 0 . 8 \%}$ \\
\hline
\end{tabular}

\section{TESTS ON PLASTIC FINES-CLAY}

The clay particles were used as the plastic fines. Tests were conducted in the laboratory to determine the properties such as moisture content, liquid limit, plastic limit, and shrinkage limit, specific gravity, maximum dry density, Percentage of clay, Percentage of silt, cohesive strength.

The various tests that were conducted in the laboratory to determine these properties are:

a) Oven dry method

b) Atterberg limit

c) Pycnometer test

d) Standard Proctor compaction test

e) Hydrometer analysis

f) Unconfined compressive strength test

VIII. PROPERTIES OF CLAY

The properties of clay obtained are summarized in the table IV

Table IV Properties of Clay

\begin{tabular}{|l|l|}
\hline Property & Values obtained \\
\hline Moisture content & $14.1 \%$ \\
\hline Liquid limit & $48 \%$ \\
\hline Plastic limitic limit & 120 \\
\hline Shrinkage limit & 12 \\
\hline Specific gravity & 6 \\
\hline Maximum dry density & 2.87 \\
\hline Percentage clay & $1.59 \mathrm{~g} / \mathrm{cm}^{3}$ \\
\hline Percentage silt & $76 \%$ \\
\hline Cohesive strength & $24 \%$ \\
\hline
\end{tabular}

IX. MODEL ANALYSIS

The description of the MODEL is as follows,

Tank $18 \mathrm{~mm}$ thick

Tank $28 \mathrm{~mm}$ thick

Tank $36 \mathrm{~mm}$ thick

Tank 4 6mm thick

$1 / 20^{\text {th }}$ hp pump

Connecting pipes
Size $(45 \times 45 \times 120)$ in $\mathrm{cm}$

Size $(45 \times 45 \times 45)$ in $\mathrm{cm}$

Size $(30 \times 30 \times 45)$ in $\mathrm{cm}$

Size $(30 x 30 \times 45)$ in $\mathrm{cm}$ 
The experimental setup is shown in the figure 1 .The connections are sealed using sealing material (M- seal).The required head is calculated from the equation 1.The tank 1 supplies water to the tank 2.The tank 2 maintains the head of water. Tank 3 contains the soil with a perforated plate at the bottom. The figure 2 shows the model setup.

The sand is filled at a density of $1.6 \mathrm{~kg} / \mathrm{m}^{3}$. Now the quick sand condition is checked by dropping any object on the surface of the soil.

The over flowing water from the sand beaker is taken to another beaker kept below and this water is pumped to the water supply beaker .Hence the water is cycled continuously and the quick condition is maintained throughout. Quick sand condition occurred at a head of $117.7 \mathrm{~cm}$.

\section{CALCULATION OF HEAD REQUIRED FOR QUICK SAND CONDITION}

The required head is given by

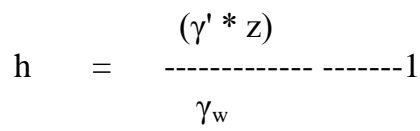

Where,

$$
\begin{aligned}
\mathrm{z} & =110 \mathrm{~cm} \\
\gamma^{\prime} & =1070.1 \mathrm{~kg} / \mathrm{m} 3 \\
\gamma_{\mathrm{w}} & =1000 \mathrm{~kg} / \mathrm{m} 3 \\
\mathrm{~h} & =1.07 \times 110 \\
& =117.7 \mathrm{~cm} .
\end{aligned}
$$



Fig 1: Experimental set up

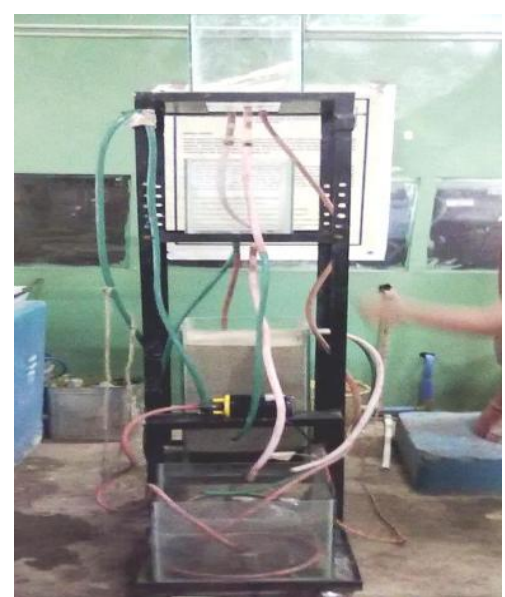

Fig 2 figure showing the model setup 
The figures 3.1 and 3.2 show the quick sand condition and the head of water required for the quick sand condition to occur.

\section{QUICK SAND CONDITION OF FINE SAND}

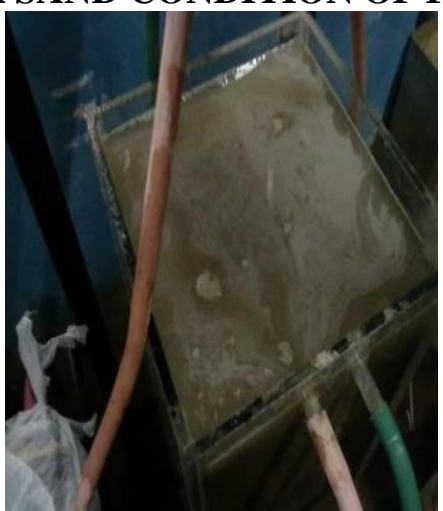

Fig 3.1 Boiling condition of the sand

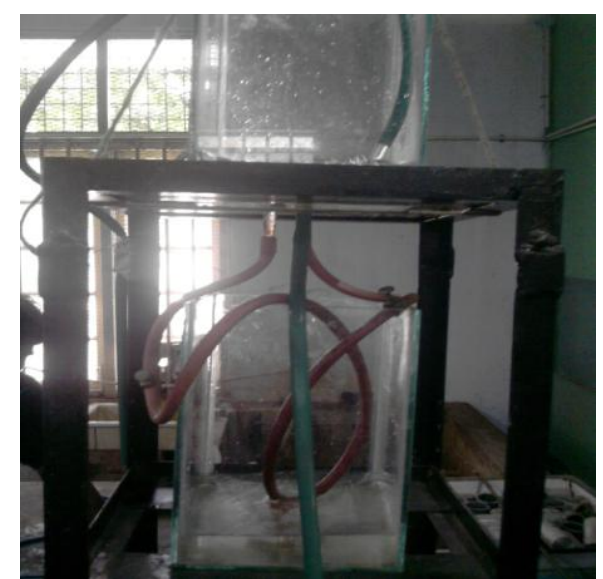

Fig 3.2 Head of water at boiling condition

\section{EFFCTS OF NON PLASTIC FINES ON THE LIQUEFACTION RESISTANCE OF SAND}

The model study was performed on fine sand by varying the percentage of silt as $1 \%$ and $2 \%$.As the percentage of fine increases the resistance to liquefaction also increases.

It was seen that the head required for the quick sand condition to occur was when $1 \%$ silt is added is $119 \mathbf{c m}$.

The figures 4.1 and 4.2 show the boiling condition and the head of water required to cause liquefaction when $1 \%$ silt is added.

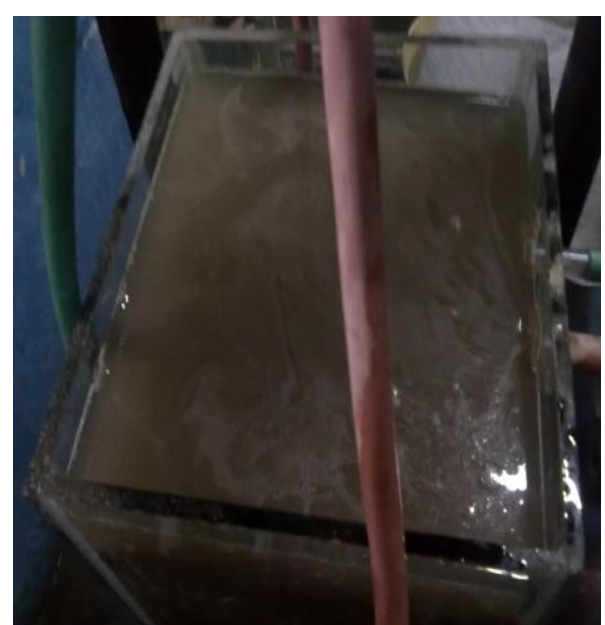

Fig 4.1: Boiling condition of the sand with $1 \%$ silt 


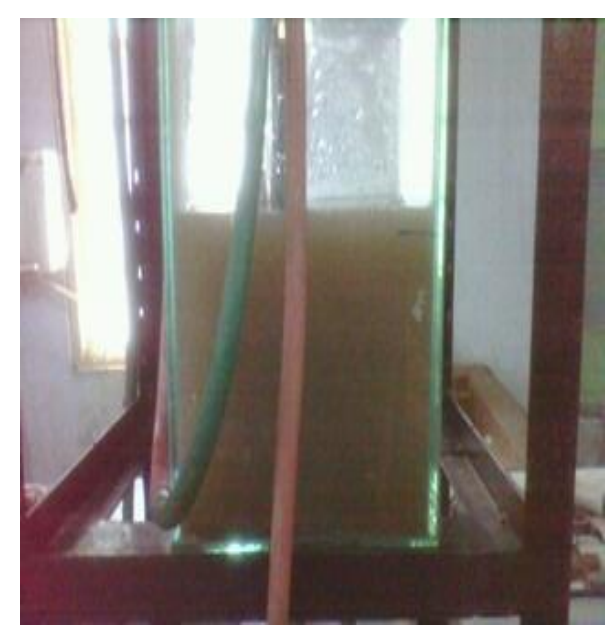

Fig 4.2: Figure showing the constant head

The head of water required to cause quick sand condition when $2 \%$ silt is added is $\mathbf{1 2 0 . 2} \mathbf{c m}$

\section{EFFCTS OF PLASTIC FINES ON THE LIQUEFACTION RESISTANCE OF SAND}

As the clay is added to sand the cohesion increases as a result the strength of the soil increases. The liquefaction resistance of the sample increases resulting in the increase of the head of water

The head of water necessary to cause liquefaction of the sample with $1 \%$ clay is $\mathbf{1 2 8} \mathbf{c m}$.

The figures 5.1 and 5.2 show the boiling condition and the head of water required to cause liquefaction when $1 \%$ clay is added.

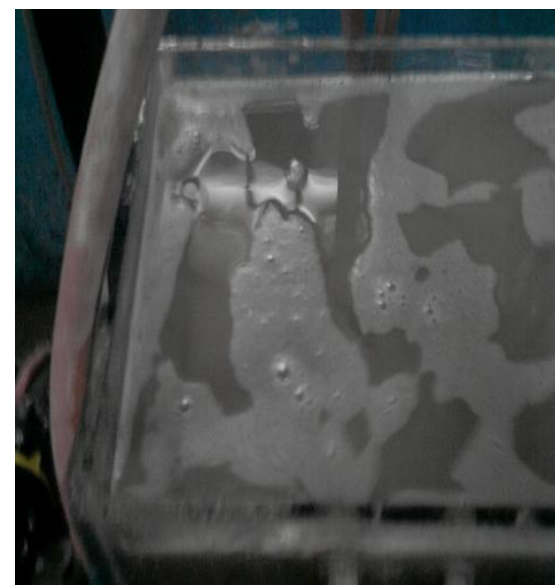

Fig 5.1Boiling condition of sand with $1 \%$ clay

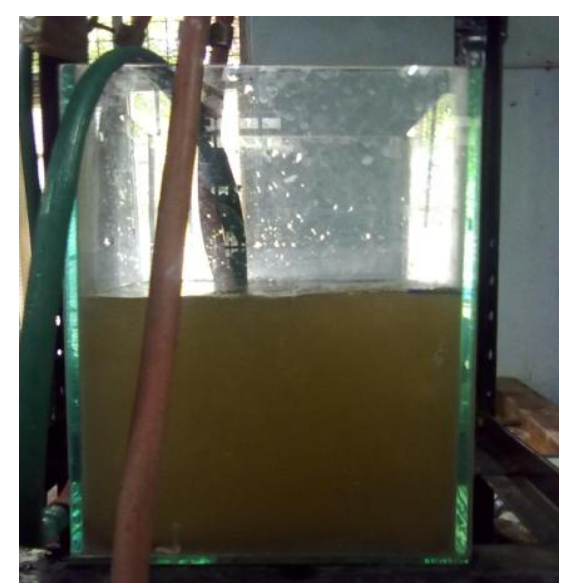

Fig 5.2 Figure showing the constant head 
$2 \%$ clay is added to the total weight of the sandy soil. The liquefaction is resisted to a very large extent. It was observed that the head of water that is required to cause the boiling condition was $140 \mathrm{~cm}$.

\section{VERIFICATION OF THE OCCURANCE OF THE QUICK SAND CONDITION}

A stone dropped at the surface of the tank reached the bottom of the tank in no time. This is proved with the following figures 6.1 and 6.2 .

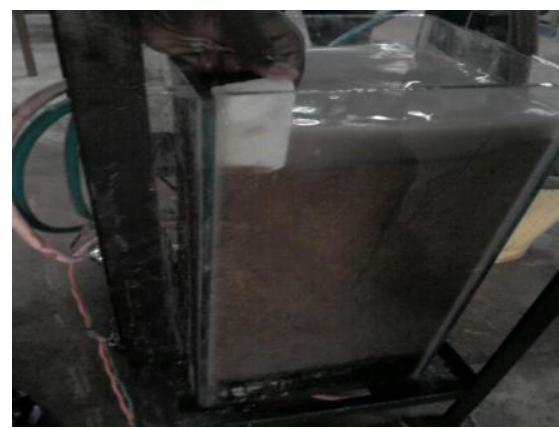

Fig 6.1The object being dropped into the tank



Fig 6.2Object at the base of the tank

XV. RESULTS \& ANALYSIS

The results obtained from the model study conducted is given in table $\mathrm{V}$

\begin{tabular}{|l|l|}
\hline Type of sample & $\begin{array}{l}\text { Head of water } \\
\text { obtained in } \mathbf{c m}\end{array}$ \\
\hline Pure fine sandy & 117.7 \\
\hline Sand with 1\% silt content & 119 \\
\hline Sand with 2\% silt content & 120.2 \\
\hline Sand with 1\% clay content & 128 \\
\hline Sand with 2\% clay content & 140 \\
\hline
\end{tabular}

\section{DISCUSSIONS}

a) It is inferred that as the fines content increases the liquefaction susceptibility of the sand increases.

b) It is seen that the non plastic fines resist the liquefaction but only to a very small extent.

c) The plastic fines such as the clay resists the liquefaction to a very large extent.

d) When the quick sand condition occurs any particle which is present on the surface of the soil will be engulfed by it

\section{CONCLUSIONS}

The following conclusions were drawn from the study:

a) The head of water for sand with $1 \%$ and $2 \%$ of silt increased - increase of liquefaction resistance .

b) The head of water obtained for sand with $1 \%$ and $2 \%$ of clay increased effectively.

c) Quick sand condition - An object dropped at the surface of the soil moves in no time to the bottom

In general to keep the people out of the reach of quick sand it's better to give a brief description of quick sand and its effects rather than to simply keep a sign board simply denoting "quick sand be careful". 


\section{REFERENCES}

[1] Ishihara, K.(1996)- Soil behavior in earthquake geotechnics, The Oxford Engineering Science Series, Clarendron Press Oxford, pp 227-228

[2] Tatsuoka, F., Kato, H., Kimurs, M. and pradhan, T.B.S (1998)- Liquefaction strength of sands subjected to sustained pressure, Soils and foundations,Vol:28,No.1.,pp 119-131

[3] Vaid, V.P. and Thomas, J.(1995),"Liquefaction and post liquefaction behavior of sand," Journal of GeotechnicalEngineering,Vol.121,no.2,pp.163-173

[4] Shomoto, Y,Zhang, J.m, and Ghoto, S,(1997) mechanism of large post-liquefaction deformation in saturated sand, Soils and Foundations,37(2),pp.71-80

[5] Cundall,P.A. and Strack, O.D.L (1979), A Discrete numerical Model for Granular Assemblies, Geotechniques, Vol.29,No.1,pp 47-65 6

[6] Rotenburg,L. And Bathurst,R.J. (1989) Analytical Study of Induced Anisotropy In Idealised Granular Materials,Geotechnique,vol.39(4),pp.601-614

[7] Sitharam,T.G, Dinesh, S.V and Shimzu,N.(2002) micromechanical modeling of monotonic shear behavior of granular media using three dimensional DEM, International conference micromechanics of granular media, Powder and Grains,2005, University of Stuttgart, Germany, pp 257-260

[8] Xenaki, V.C., and Anthanasopoulos, G.A., (2003),"liquefaction resistance of sand-mixtures: An experimental investigation of the effect of fines." Soil Dynamics and Earthquake Engineering, pp 183-194

[9] Shibata, t., and Teparaksa,W.,(1988)."Evaluation Of Liquefaction potentials of soils Using Cone Penetration Tests" Soils and Foundations, JSSMFE, Vol.28,no.2,pp.49-60

[10] Silver,M., Chan,C., Ladd,R., Lee,K., Tiedmann,D., Townsend,F., Valera,J., Wilson,J.,(1976)."Cyclic Strength of Standard Test Sand" Journal of the Geotechnical Engineering Division,ASCE,Vol.102(5),pp.511-523

[11] Lee,k.,and Singh, A(1971)"Compaction of Granular soils “"Journal of the Soil Mechanics and Foundation Division",ASCE,Vol.93,SM5,pp.169-190

[12] De Alba,P., Seed., and Chan,C., (1976)." Sand liquefaction in Large Simple Shear Tests"” Journal of Geotechnical Engineering, ASCE,Vol.93(6),pp.237-260

[13] El Hosri, M.S., Biarez, J.,and Hicher, P.Y.,(1982).’'Liquefaction Characteristic of Silty clay” Proceedings of the $8^{\text {th }}$ World Conference on Earthquake Engineering,Sanfrancisco,USA,PP.277-284.

[14] Florin, V.A., and Ivanov, P.L., (1961). "Liquefaction of Saturated Sandy Soils" Proceedings of the $5^{\text {th }}$ International Conference on Soil Mechanics and Foundation Engineering, Paris, France, Vol. 1, pt. 107 to 111. 